\title{
Use of high-resolution NWP rainfall and river flow forecasts for advance warning of the Carlisle flood, north-west England
}

Article

Accepted Version

Roberts, N. M., Cole, S. J., Forbes, R. M., Moore, R. J. and Boswell, D. (2008) Use of high-resolution NWP rainfall and river flow forecasts for advance warning of the Carlisle flood, north-west England. Meteorological Applications, 16 (1). pp. 23-34. ISSN 1469-8080 doi: https://doi.org/10.1002/met.94 Available at https://centaur.reading.ac.uk/31223/

It is advisable to refer to the publisher's version if you intend to cite from the work. See Guidance on citing.

Published version at: http://dx.doi.org/10.1002/met.94

To link to this article DOI: http://dx.doi.org/10.1002/met.94

Publisher: Royal Meteorological Society

All outputs in CentAUR are protected by Intellectual Property Rights law, including copyright law. Copyright and IPR is retained by the creators or other copyright holders. Terms and conditions for use of this material are defined in the End User Agreement.

www.reading.ac.uk/centaur 
Central Archive at the University of Reading

Reading's research outputs online 


\title{
Use of high-resolution NWP rainfall and river flow forecasts for advanced warning of the Carlisle flood
}

\author{
Nigel Roberts, ${ }^{1 *}$ Steven J. Cole ${ }^{2}$, Richard Forbes ${ }^{1}$, Robert J. Moore ${ }^{2}$ and Daniel \\ Boswell ${ }^{3}$, \\ ${ }^{1}$ Met Office, Joint Centre for Mesoscale Meteorology, Meteorology Building, \\ University of Reading, PO Box 243, Earley Gate, Reading, Berkshire, RG6 6BB, UK \\ ${ }^{2}$ Centre for Ecology and Hydrology, Joint Centre for Hydro-Meteorological Research, \\ Wallingford, Oxon, OX10 8BB, UK \\ ${ }^{3}$ Environment Agency, PO Box 12, Knutsford Road, Warrington WA4 1HG, UK
}

\begin{abstract}
On the $8^{\text {th }}$ January 2005 the city of Carlisle in northwest England was severely flooded following two days of almost continuous rain over the nearby hills. Orographic enhancement of the rain through the seeder-feeder mechanism led to the very high rainfall totals. This paper shows the impact of running the Met Office Unified Model (UM) with a grid spacing of 4 and $1 \mathrm{~km}$ compared to the $12 \mathrm{~km}$ available at the time of the event. These forecasts, and forecasts from the Nimrod nowcasting system, were fed into the Probability Distributed Model (PDM) to predict river flow at the outlets of two catchments important for flood warning. The results show the benefit of increased resolution in the UM, the benefit of coupling the highresolution rainfall forecasts to the PDM and the improvement in timeliness of flood warning that might have been possible.
\end{abstract}

High-resolution NWP hydrological modelling flood prediction orographic rainfall 


\section{Introduction}

On the $8^{\text {th }}$ January 2005 widespread flooding affected the county of Cumbria in northern England. Heavy continuous rain over a prolonged period gave exceptional rainfall totals, with Honister in the Lake District recording $213 \mathrm{~mm}$ in the 48 hours ending at 12 UTC on the $8^{\text {th }}$ January. The resulting floods affected around 2600 properties in the region and caused significant damage to infrastructure and the local economy. The estimated scale of the losses is in excess of $£ 450$ million (Environment Agency, 2005, 2006).

The city of Carlisle was badly affected by the River Eden and its tributaries (primarily the Caldew and Petteril) overtopping defences. Over 1900 properties were flooded in Carlisle alone and tragically two people died. The same storm system also caused serious flooding at many other locations including the Conwy Valley in Wales, the Upper Ouse and Upper Tyne in northeast England and the rivers Tay and Ness in Scotland.

A significant part of the reason why so much rain fell on this occasion was due to the effect the Cumbrian mountains had on enhancing the rainfall rates locally over a sustained period of time. The orographic enhancement is thought to have occurred primarily because of the so-called 'seeder feeder' mechanism (Bader and Roach, 1977; Browning, 1980; Lean, 2002) in which frontal rain becomes heavier as it falls through lower-level orographically produced cloud. It happens mostly in the warm sectors of depressions near to the cold-frontal zone, as was the case here, and is thought to account for a large proportion of the orographic rainfall in the UK.

In these types of flood-risk situation, it is vital to be able to provide as much advance warning as possible. To do this depends on having both accurate rainfall forecasts and accurate prediction of river flow based on those forecasts. Often, rainfall forecasts are not accurate enough because the skill of advection 'nowcasting' methods (e.g. the Met Office Nimrod system (Golding, 1998)) usually only extends to a few hours and Numerical Weather Prediction (NWP) model forecasts, even if skilful, have had insufficient resolution to represent local orographic effects or provide information on the scales required by hydrological models. It is hoped, therefore, that an improvement in the accuracy and applicability of rainfall forecasts can be achieved by an increase in the resolution of NWP models. This should be particularly true for situations like the one discussed here in which stratiform rain is modulated by orography. Westrick and Mass (2001) used output from 36, 12 and 4 km NWP model simulations as input into a hydrological model and showed that for an orographically enhanced stratiform rainfall event in the northwest of the USA, the $4 \mathrm{~km}$ forecasts gave the best results. They attributed this mostly to a more accurate representation of the orography. Convective rainfall, on the other hand, presents more serious difficulties and should be treated in a much more probabilistic framework (Roberts and Lean, 2008), and is outside the scope of this paper.

High-resolution NWP models (grid spacing less than $5 \mathrm{~km}$ ) are now becoming standard for short-range forecasting. The Met Office Unified Model (UM) (Davies et al., 2005) is now run operationally with a horizontal grid-spacing of $4 \mathrm{~km}$. The finest resolution available operationally in January 2005 was $12 \mathrm{~km}$. Implementation of a $\sim 1.5 \mathrm{~km}$ model is expected by the end of the decade. 
The vision for the future is that automated end-to-end systems that feed highresolution NWP rainfall forecasts into hydrological models will become a standard part of the flood warning procedure. This paper will examine the impact of increasing horizontal and vertical resolution of NWP model forecasts on predictions of river flow for this particular event and draw some more general conclusions from those results. To do this, rainfall forecasts from the Met Office Unified model run with a grid spacing of 12,4 and $1 \mathrm{~km}$ were fed into the Probability Distributed Model (PDM) rainfall-runoff model (Moore, 1985, 2007) for two selected river catchments.

The paper is organised as follows. In section 2 the case study and the seeder-feeder mechanism will be described in more detail; in section 3 the NWP model configurations will be described and results from the model forecasts presented; in section 4 the PDM model and the selected catchments will be discussed and the results from feeding NWP forecasts into the PDM presented, and in section 5 conclusions will be drawn.

\section{What happened}

During the $7^{\text {th }}$ and through into the early hours of the $8^{\text {th }}$ of January 2005 the northwest of England was under the influence of a warm and very moist southwesterly air flow. A quasi-stationary waving frontal system brought a period of almost continuous rain to much of Cumbria (Figure 1). Very large quantities of rain were measured over the mountains of the Lake District and the Pennines. Honister in the Lake District (see location in Figure 2) received the highest recorded total of $213 \mathrm{~mm}$ in the 48 hours ending at 12 UTC on the $8^{\text {th }}$ January, of which $112.6 \mathrm{~mm}$ fell in the 12-hour period between 12 UTC on the $7^{\text {th }}$ and 00 UTC on the $8^{\text {th }}$. Another dozen sites recorded more than $150 \mathrm{~mm}$ in the 48 -hour period. It was both the persistent nature of the synoptic pattern and the enhancement of the rainfall over hills that led to the very high rainfall totals and flooding. River flows in the Eden peaked at approximately $1500 \mathrm{~m}^{3} \mathrm{~s}^{-1}$ and at Eden Bridge the river level was about $1 \mathrm{~m}$ higher than the 1822 flood mark. Flooding was extensive causing property damage and loss of life in the vicinity of Carlisle.

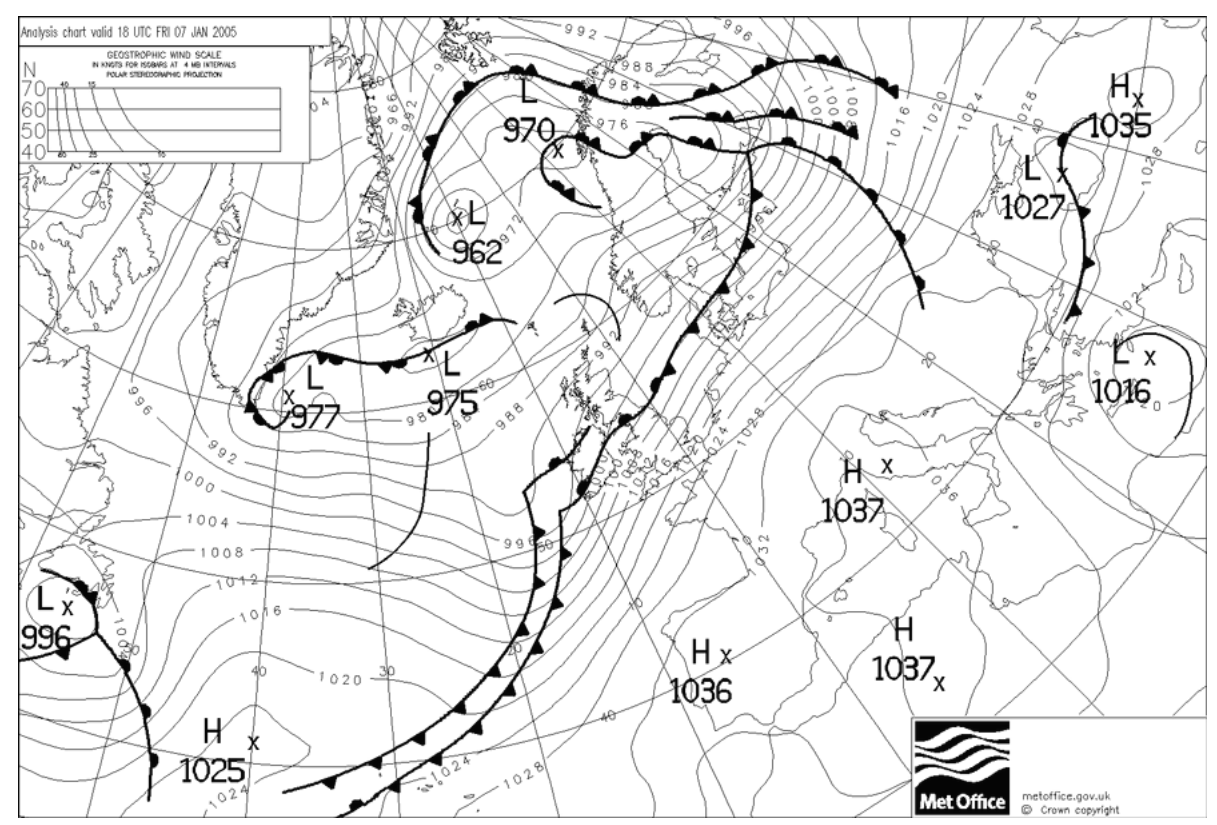

Figure 1. Synoptic chart for 18 UTC $7^{\text {th }}$ January 2005, courtesy of the National Climate Information Centre (NCIC) 
The observed rainfall for the 24-hour period starting 00 UTC on the $7^{\text {th }}$ is shown in Figure 2. The largest total in that period was $173 \mathrm{~mm}$ at Honister (for location see Figure 2b). It is noticeable that the rainfall amounts estimated by the radar network were generally less than that measured by gauges and distributed somewhat differently. The disadvantage the radar network has over the Cumbrian region is that there are no radars nearby. This means that the horizontal resolution is necessarily limited to $5 \mathrm{~km}$ squares. Also, the radar scans are too high to see low-level precipitation, and this can result in a significant underestimation of the rainfall when there is orographic enhancement through the seeder-feeder mechanism (see section 2). Because of this, the radar estimate includes an allowance for orographic enhancement, but this appears to have been insufficient on this occasion..

The most accurate measurements of the true rainfall totals should therefore come from the rain gauge data, and for that reason, the hand analysis of the raingauge data was constructed (Figure 2a). Despite the inevitable spatial uncertainty within the more data-sparse areas, we think this analysis gives a satisfactory picture of the rainfall distribution.

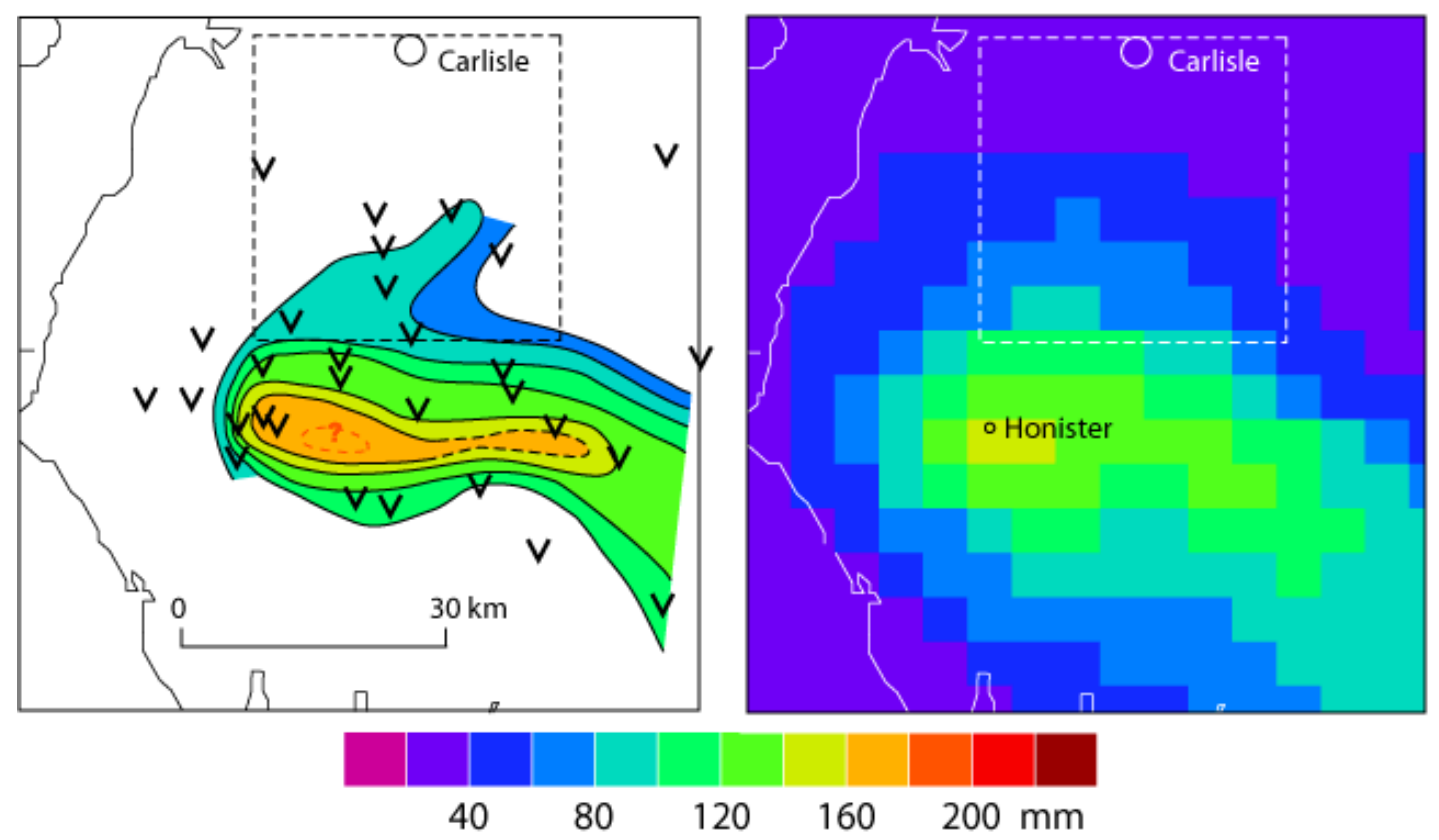

Figure 2. Rainfall accumulations over the 24-hour period starting 00 UTC 7 January 2005 from (a) hand contouring through the highest recording rain gauges, located at the base of each ' $V$ ' (the question mark indicates the possibility of higher totals in that data-void area) (b) radar (including orographic enhancement) on a $5 \mathrm{~km}$ grid. The dashed square marks the area shown later in Figure 9.

\subsection{The seeder-feeder mechanism}

The orographic enhancement of the rain was largely due to the seeder-feeder mechanism (Bader and Roach, 1977; Browning, 1980; Lean and Clark, 2003). A schematic of this is shown in Figure 3. Cloud forms when a flow of very moist lowlevel air is forced to rise over hills. This layer of stratus cloud will typically not be deep enough to produce much rain in the time it takes the air to cross the hills. However, if rain is falling from higher-level (e.g. frontal) cloud it will capture cloud droplets as it 
falls through this low-level orographic cloud. In doing so the rainfall will be considerably enhanced at ground level. Such enhancement happens mostly in the warm sectors of depressions near to the cold-frontal zone and is thought to account for a large proportion of the orographic rainfall in the UK. On this occasion, all the necessary ingredients were in place: a strong and almost saturated low-level southwesterly flow with a high wet-bulb potential temperature (for wintertime) was forced to ascend over the Cumbrian mountains beneath a precipitating frontal zone. This situation persisted for more than 36 hours.

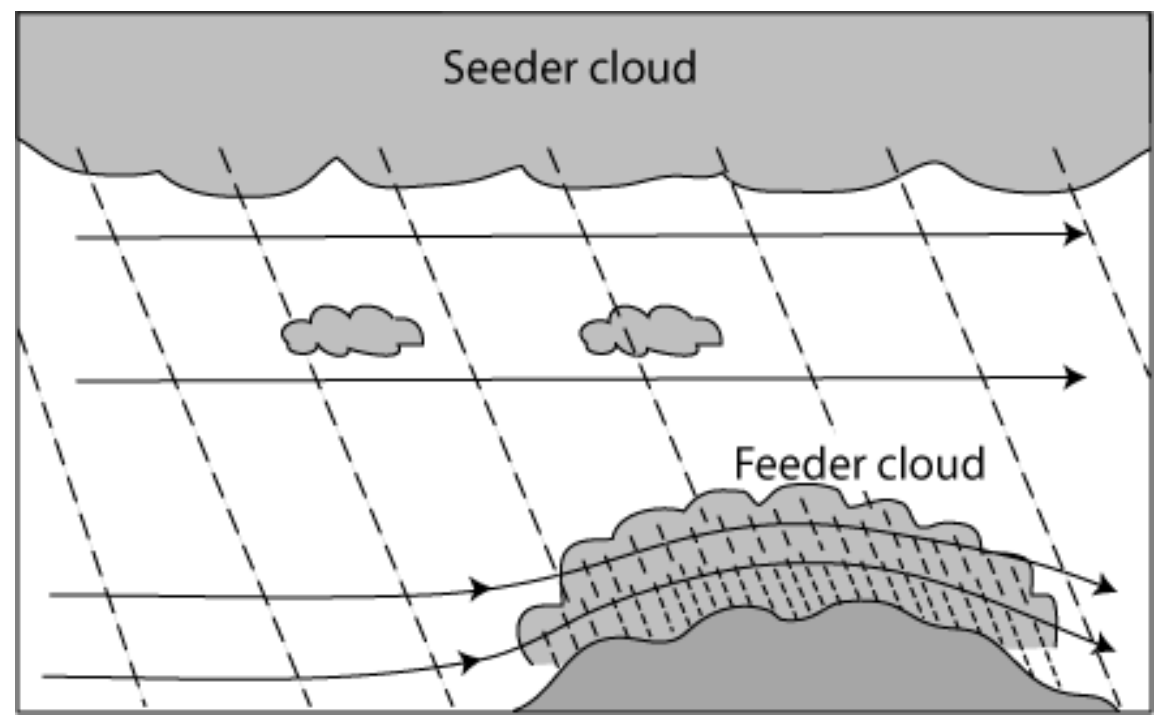

Figure 3. A schematic of the seeder-feeder mechanism adapted from the Met Office Forecasters' Reference Book. See text for more information.

\section{The NWP model forecasts}

\subsection{The NWP model setup}

The NWP model used was the Met Office Unified Model (UM) (Davies et al., 2005). The UM is non-hydrostatic and includes a comprehensive set of parametrizations, including surface exchange (Essery et al., 2001), boundary layer (Lock et al., 2000), mixed phase cloud microphysics (Wilson and Ballard, 1999) and convection (Gregory and Rowntree, 1990). Since their first implementation there have been additions to these parametrizations; most notable for this study is the inclusion of a prognostic rain variable in the microphysics scheme (which allows rain to be blown horizontally by the wind as well as falling vertically). The model runs on a rotated latitude/longitude horizontal grid with Arakawa $\mathrm{C}$ staggering, and, a terrain-following hybrid-height vertical coordinate with Charney-Philips staggering.

The UM was run with a horizontal grid spacing of 12,4 and $1 \mathrm{~km}$ on the domains shown in Figure 4 . The $12 \mathrm{~km}$ domain is the same as that used operationally at the time (the mesoscale model). It has now been superseded by the $12 \mathrm{~km}$ North Atlantic European (NAE) model, which covers much of the north Atlantic and western Europe. The $4 \mathrm{~km}$ domain is the same as that used for the UK $4 \mathrm{~km}$ model, which went fully operational in summer 2007 (so was not available at the time of this event). The 12 $\mathrm{km}$ and $4 \mathrm{~km}$ configurations were run with 38 vertical levels that are spaced a few tens of metres apart near the surface and separate out to a few hundred metres apart in the mid-troposphere. The $1 \mathrm{~km}$ model had 76 vertical levels, doubling the 
vertical resolution. The $12 \mathrm{~km}$ forecasts supplied the boundary conditions for the 4 $\mathrm{km}$ forecasts, which in turn supplied the boundary conditions for the $1 \mathrm{~km}$ forecasts.

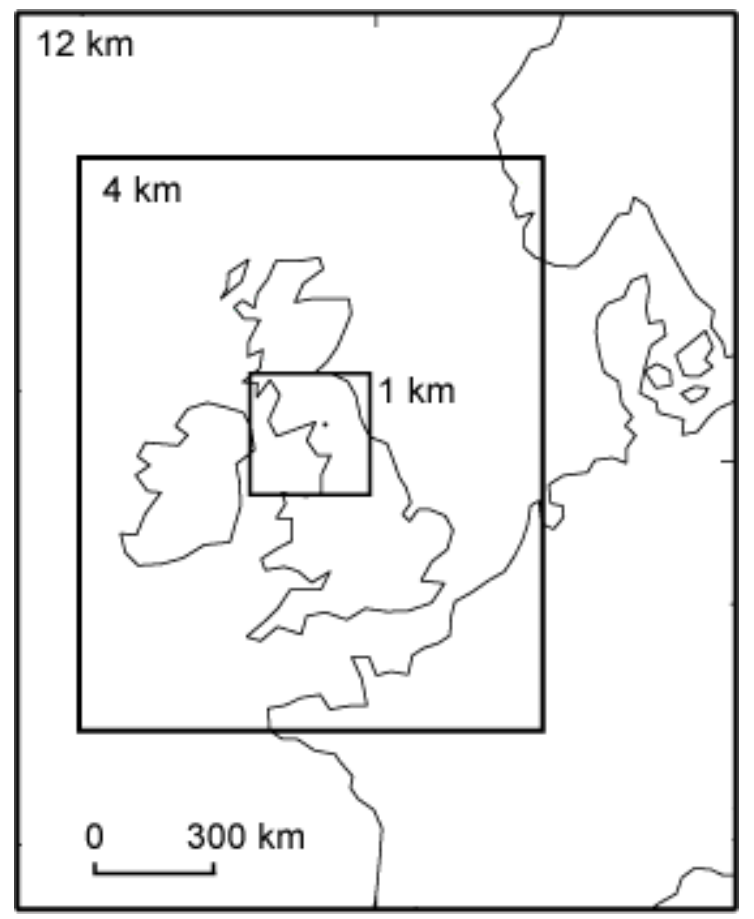

Figure 4. The 12, 4 and $1 \mathrm{~km}$ model domains used.
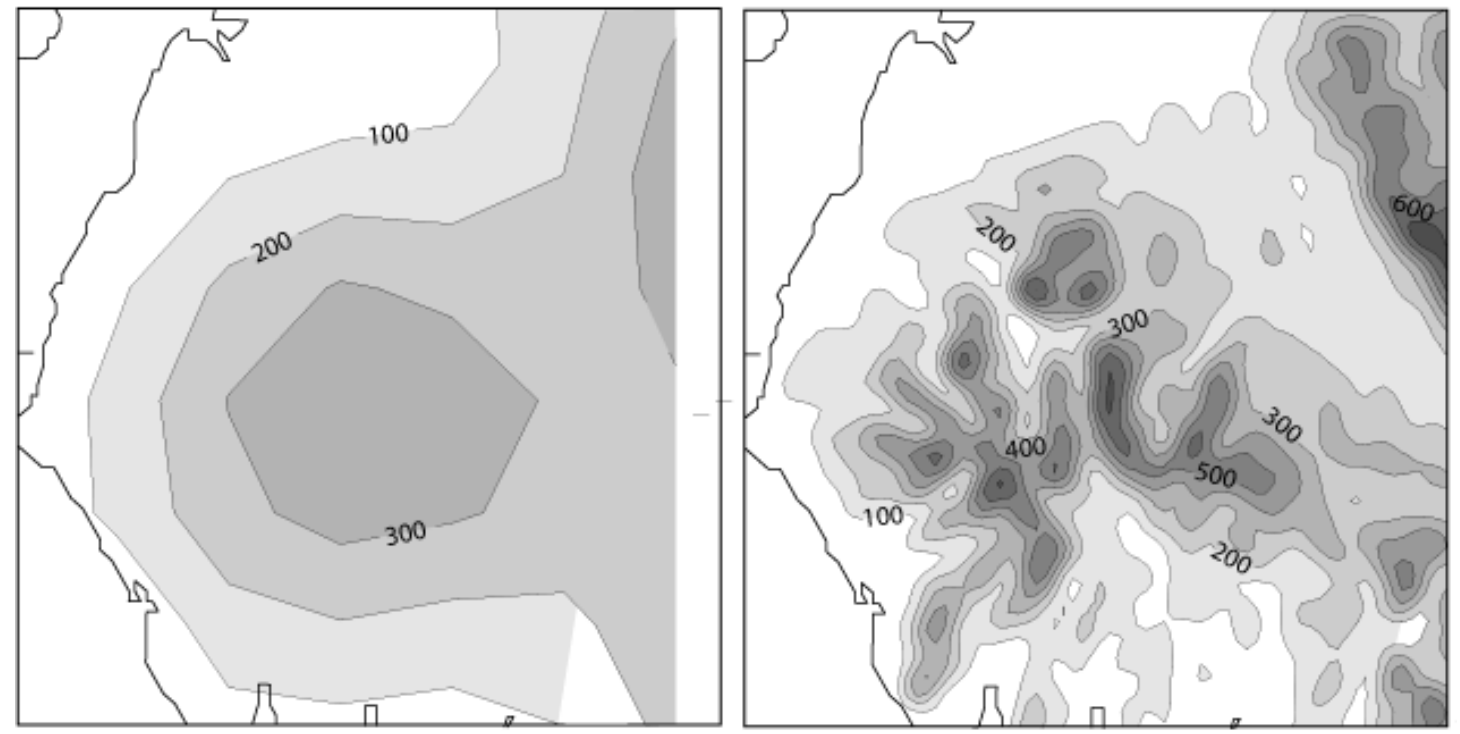

Figure 5. The orography used in (a) the $12 \mathrm{~km}$ model and (b) the $1 \mathrm{~km}$ model. The $1 \mathrm{~km}$ orography was smoothed with a Raymond filter using a value of 4 for $\mathcal{E}$ (Raymond, 1988).

It is known that the UM dynamics and cloud microphysics scheme are capable of representing the seeder-feeder mechanism (Lean, 2002), and therefore the orographic enhancement of rainfall. However, the particular advantage a finerresolution model has is a much more accurate representation of the orography (Figure 5) and for that reason should give more accurate rainfall forecasts in this type 
of situation, especially on more local scales and over smaller river catchments. Part of the purpose of this work was to investigate whether that was indeed the case for the January 2005 event.

\subsection{The model runs}

Five sets of forecasts (FC1 to FC5 in Figure 6) were run starting from 18 UTC on the $6^{\text {th }}$ January, and $00,06,12,18$ UTC on the $7^{\text {th }}$ January. Each set consisted of a 12,4 and $1 \mathrm{~km}$ forecast. The $12 \mathrm{~km}$ model is essentially the same as the $12 \mathrm{~km}$ mesoscale model that was operational at the time. It used operational 3D-Var (Lorenc et al., 2000) and latent heat nudging (Jones and Macpherson, 1997) data assimilation techniques to obtain the best fit to observations at the start. The 4 and $1 \mathrm{~km}$ models both used fields interpolated from the $12 \mathrm{~km}$ model 1-hour into the $12 \mathrm{~km}$ forecast with no additional data assimilation (i.e. for a $12 \mathrm{~km}$ forecast starting from 00 UTC, the 4 and $1 \mathrm{~km}$ forecasts started from the $12 \mathrm{~km}$ fields at $01 \mathrm{UTC})$.

Since the 4 and $1 \mathrm{~km}$ models had to 'spin up' from coarser resolution information, the first two hours of the forecasts were not examined. This does not affect the usefulness of the results, since, in an operational context, the first 2 to 3 hours of a forecast are not usually available to decision makers anyway because of the time it takes to run the forecasts and disseminate the information.

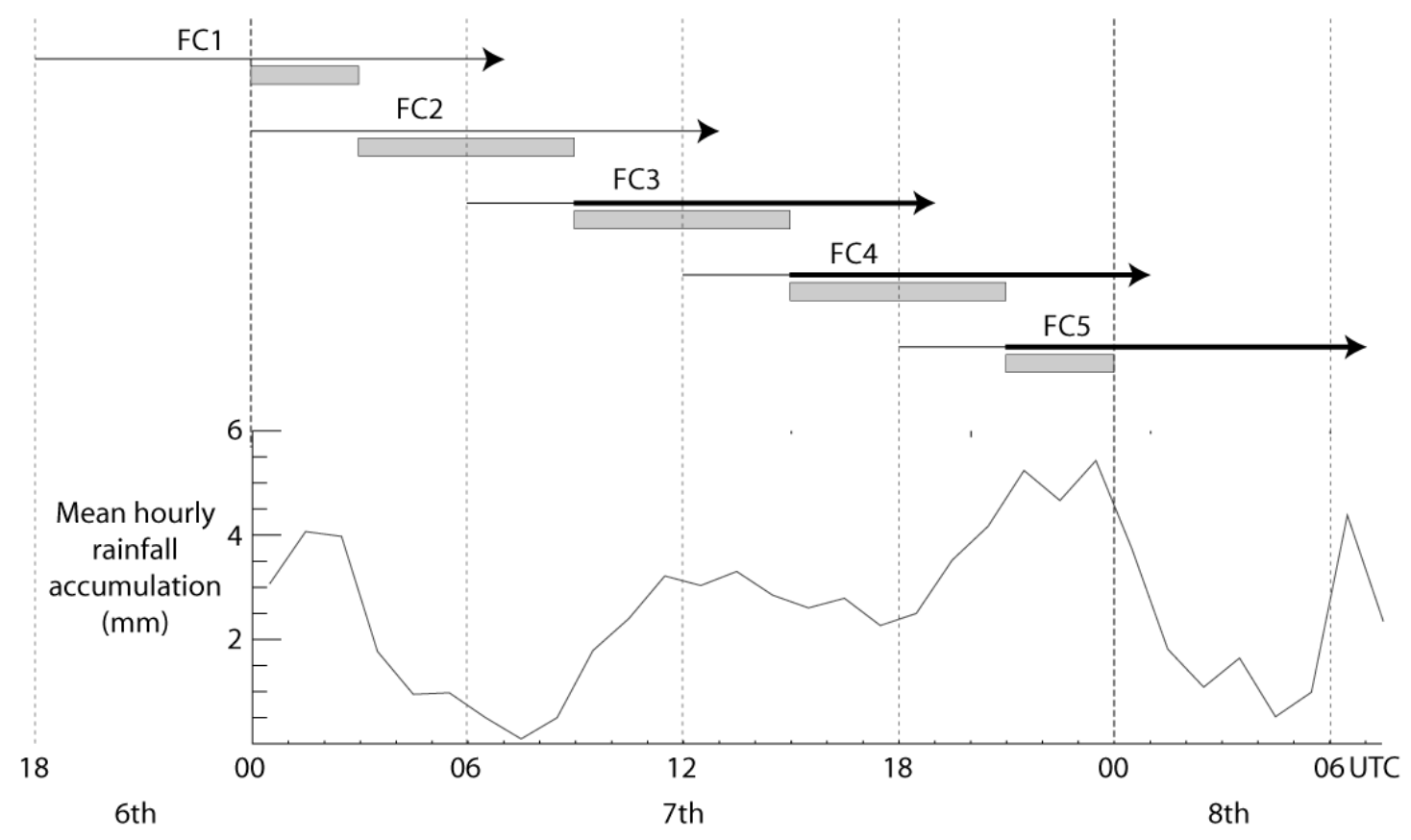

Figure 6. A schematic of the five sets of forecast runs (arrows), labelled FC1 to FC5. Each forecast set consists of a 12, 4 and $1 \mathrm{~km}$ model run. The grey bars show the parts of each forecast set extracted for the 24-hour rainfall accumulation composites discussed in section 3.3. The bold parts of the arrows in FC3, FC4 and FC5 indicate the rainfall accumulations that were input into the PDM model (section 4). The graph shows the hourly rainfall accumulations during the 31hour period starting 00 UTC 7 January 2005 over an area slightly smaller than shown in Figures $2,5,7 \& 8$. See text in section 3 for more information. 
The forecasts were examined in two ways. Firstly, the forecast rainfall accumulations were compared with radar and rain gauge estimates over the 24-hour period starting 00 UTC on the $7^{\text {th }}$ January. To do this, the periods shown by the grey bars in Figure 6 (for each of the sets of forecasts) were extracted and pieced together. The resulting composite was used to assess the performance of the predicted rainfall at each resolution for the 3- to 9-hour forecast period. Secondly, the predicted rainfall was fed into the Probability Distributed Model (PDM) rainfall-runoff model in order to assess the performance when used for river flow forecasting (discussed later in section 4). For this, the three consecutive forecast-sets FC3, FC4 and FC5, depicted by the thicker arrows in Figure 6, were used as input. The use of individual forecasts (rather than a composite forecast) is closer to the way the model would be used in an operational situation, and they cover the period when most of the rain fell.

\subsection{Results from the UM forecasts}

The composite 24-hour accumulations from each of the model resolutions are presented in Figure 7 together with estimates from rain gauges and radar. The $12 \mathrm{~km}$ model clearly produced too little rain and the highest totals fell too close to the south and west coasts rather than over the hills. In contrast, the $4 \mathrm{~km}$ model gave a much more accurate distribution of the rainfall. The rainfall totals were also much closer to those observed, although the highest amounts were probably somewhat too low. The $1 \mathrm{~km}$ model produced, probably, the most accurate distribution of the highest totals, although it appears to have generated too much rain in general.

An informative view of the radar and modelled rainfall totals is given by the more detailed comparison with rain gauges in Figure 8 . Firstly we see that, even with the orographic enhancement included, the radar estimates were too high over the windfacing up-slopes and too low over and towards the lee of the high ground.

The $12 \mathrm{~km}$ model produced around 30 to $50 \%$ too little rain over the high ground (Figure 8b); in particular over the highest areas where the model orography is most inadequate. In a seeder-feeder situation the rainfall responds to the gradient in the orography and in the $12 \mathrm{~km}$ model this is steepest closer to the south and west coasts rather than further inland where the hills actually rise. This explains why the rainfall maximum is positioned too far south and west as shown in Figure $7 \mathrm{~b}$.

The $4 \mathrm{~km}$ model gave 10 to $20 \%$ too little rain over the central peaks, but further to the southeast around $50 \%$ too much and over the northern peaks around $40 \%$ too much (Figure 8c). This pattern can also be partly explained by the orography in the 4 $\mathrm{km}$ model (not shown), which, although much more realistic than at $12 \mathrm{~km}$, is still too smooth. The smoothing acts to reduce the heights of the central peaks more than elsewhere because there is more variability in the height of the terrain in that area. In general (apart from over the central peaks), the $4 \mathrm{~km}$ forecasts tended to produce too much rain.

The differences between the $1 \mathrm{~km}$ model and gauge measurements (Figure 8d) showed less spatial variability than was the case for the $4 \mathrm{~km}$ model (Figure 8c), indicating that the 1-km model had a more accurate distribution of the rain (as was seen in Figure 7d). This is expected because of the more accurate orography. However, it generated too much rain on average. This excess ranged between around $10 \%$ too much over the central peaks to 30 to $40 \%$ too much further southeast and 40 to $50 \%$ too much over the northern peaks. 
(a)

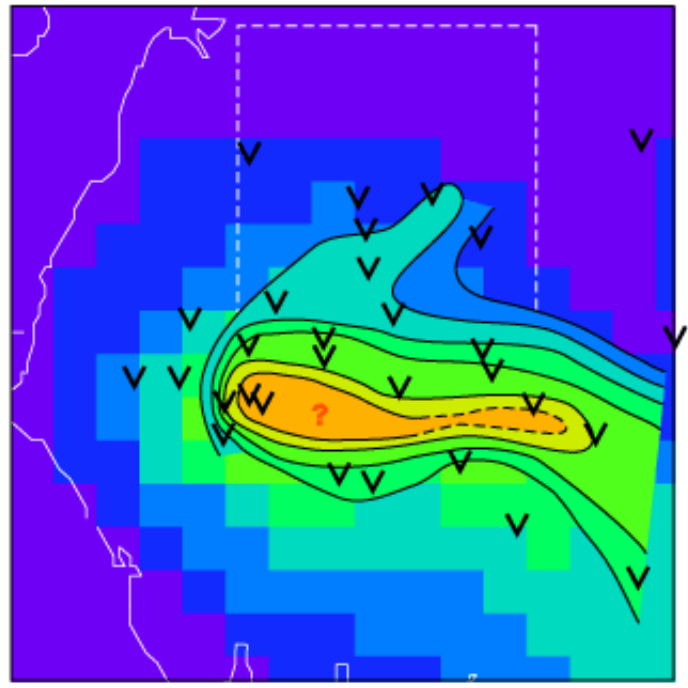

(c)

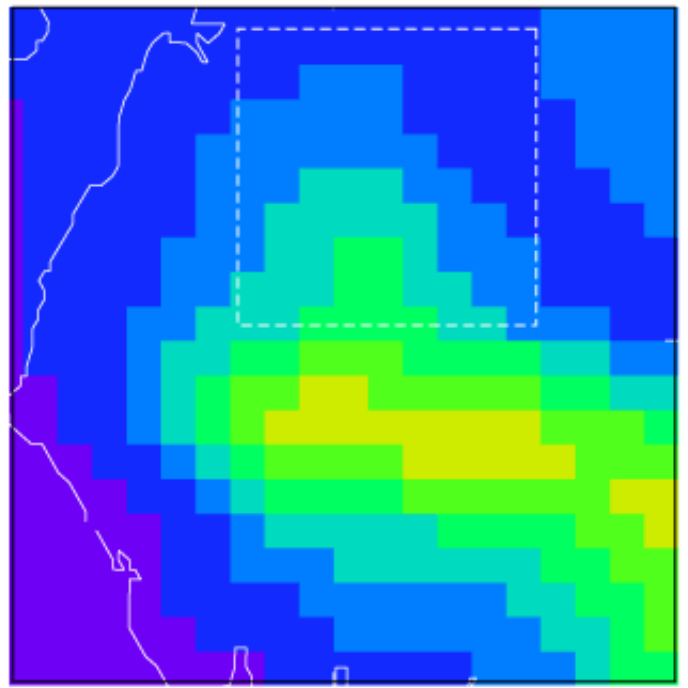

(b)

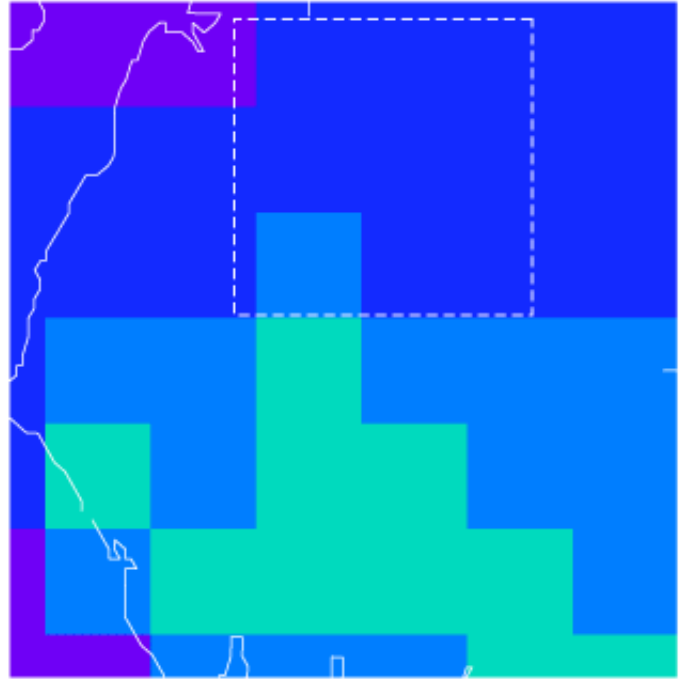

(d)

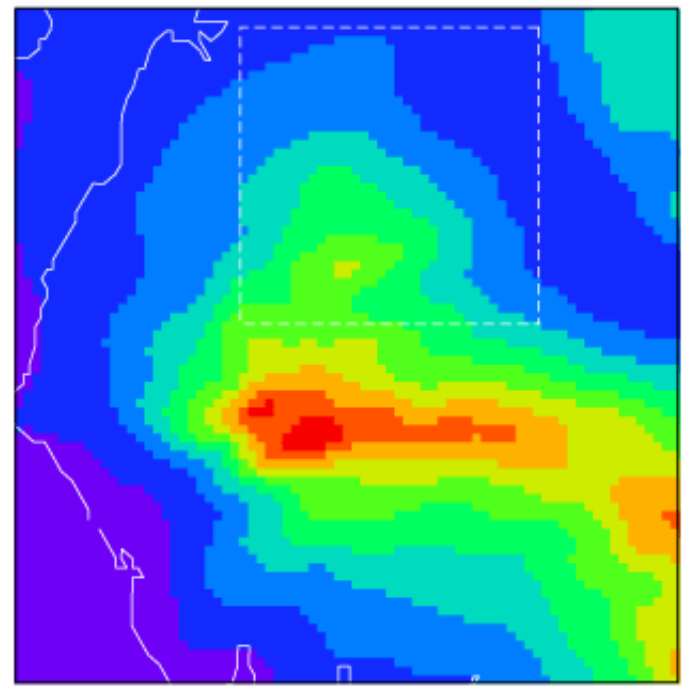

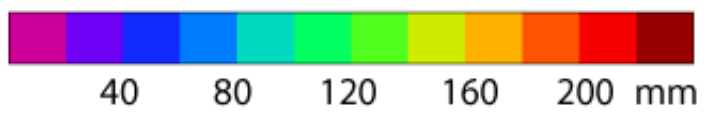

Figure 7. Map of rainfall accumulation over the 24-hour period starting 00 UTC 7 January 2005 from (a) hand contoured rain gauge measurements superimposed on radar (from Figure 2), (b) to (d) 12, 4 and $1 \mathrm{~km}$ model composites from the forecasts FC1 to FC5 (grey bars in Figure 6)

It is a concern that the $1 \mathrm{~km}$ forecasts produced too much rain as it may be indicative of a systematic bias. If there is such a bias, it cannot be detected from just one case study. However, there are other factors involved here. It is not just the response to the orography that has to be correct. The positioning and activity of the fronts, along with the characteristics of the low-level flow impacting the mountains are also important. The degree to which the amount of rain falling from the frontal 'feeder' cloud is correct or the humidity or strength of low-level flow is represented will have a major impact on the accuracy of the forecast (Lean, 2002). A comparison of the rainfall rates from the three models against radar over the Irish Sea upwind of Cumbria (where the seeder-feeder mechanism was not operating) revealed that the radar was giving only 60 to $70 \%$ of the rainfall predicted by the models over the same 24-hour period. This implies that all three model resolutions were producing too much large-scale (frontal) rain (assuming the radar to be reasonably reliable over that area). 
The problem, therefore, has got just as much to do with getting the mesoscale dynamics correct in the initial conditions as it is the response to the orography.
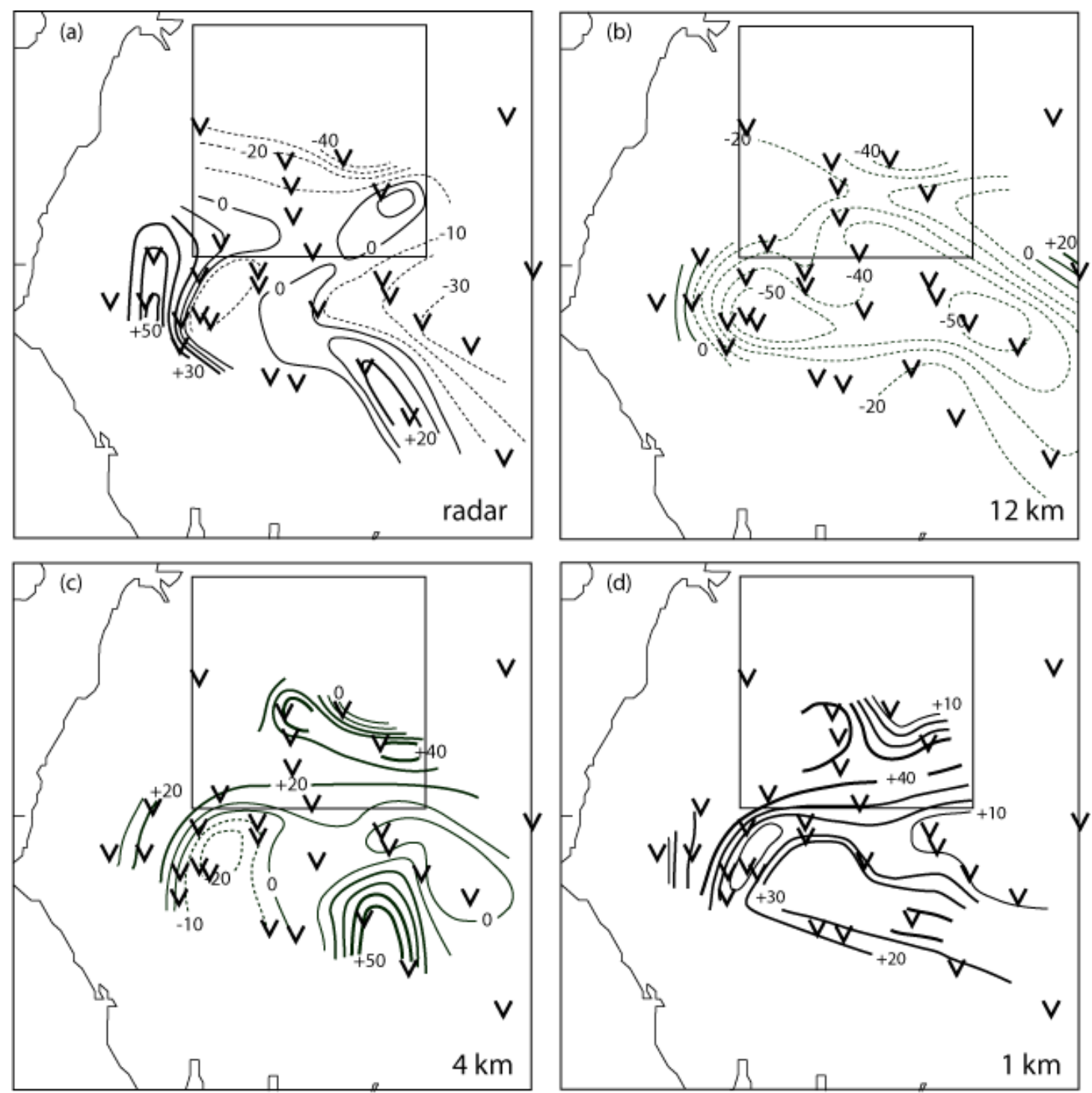

Figure 8. Map of percentage differences from rain gauge values for rainfall accumulations over the 24-hour period starting 00 UTC 7 January 2005 from (a) radar, (b) to (d) 12,4 and $1 \mathrm{~km}$ model composites from the forecasts FC1 to FC5 (grey bars in Figure 6). The square marks the area shown in Figure 9.

It is clear from these results that the $12 \mathrm{~km}$ model will be incapable of getting the correct distribution of the rainfall in a seeder-feeder situation over Cumbria because of its inadequate representation of the orography. In this case it is possible that the under-prediction over the hills would have been even worse if the frontal rain had been more accurate (lighter). It is also probable that the over-prediction of the frontal (feeder) rain played a large part in the over-prediction of the $1 \mathrm{~km}$ forecasts in this case and that the orographic enhancement associated with the seeder cloud was actually well represented. 


\section{Combining with the PDM rainfall-runoff model}

\subsection{The river catchments}

The current flood forecasting model for the Eden catchment (circa $2300 \mathrm{~km}^{2}$ ) provides a reliable 4 hour lead-time for the city of Carlisle when using only observed river level and flow data, making use of the time-of-travel from headwater river gauging stations. Longer lead-times out to 12 hours can be achieved by using observed and forecast rainfalls as input to a network of rainfall-runoff and river-flow routing models. Of course the added lead-time gained through this modelling approach, in relation to a warning based on river observations, has a trade-off through the uncertainties associated with the forecast rainfalls and the rainfall-runoff model. Here, our interest is in assessing the benefit of using high resolution NWP rainfalls with rainfall-runoff models for flood warning. Benefits will be expected to be greatest for catchments where times-of-travel are too short to forecast downstream levels with sufficient lead time.

With these considerations in mind, two adjacent tributaries of the River Eden, draining from the Cumbrian uplands northwards to Carlisle, have been chosen for rainfall-runoff modelling. The flood warning areas of these catchments cover 363 of the 4628 Carlisle properties at risk in a 1 in 1000 year flood. The Caldew catchment to the west has strong orography whilst the Petteril catchment to the east is low-lying over much of its extent (Figure 9). Thus the contrasting effects of orography on the

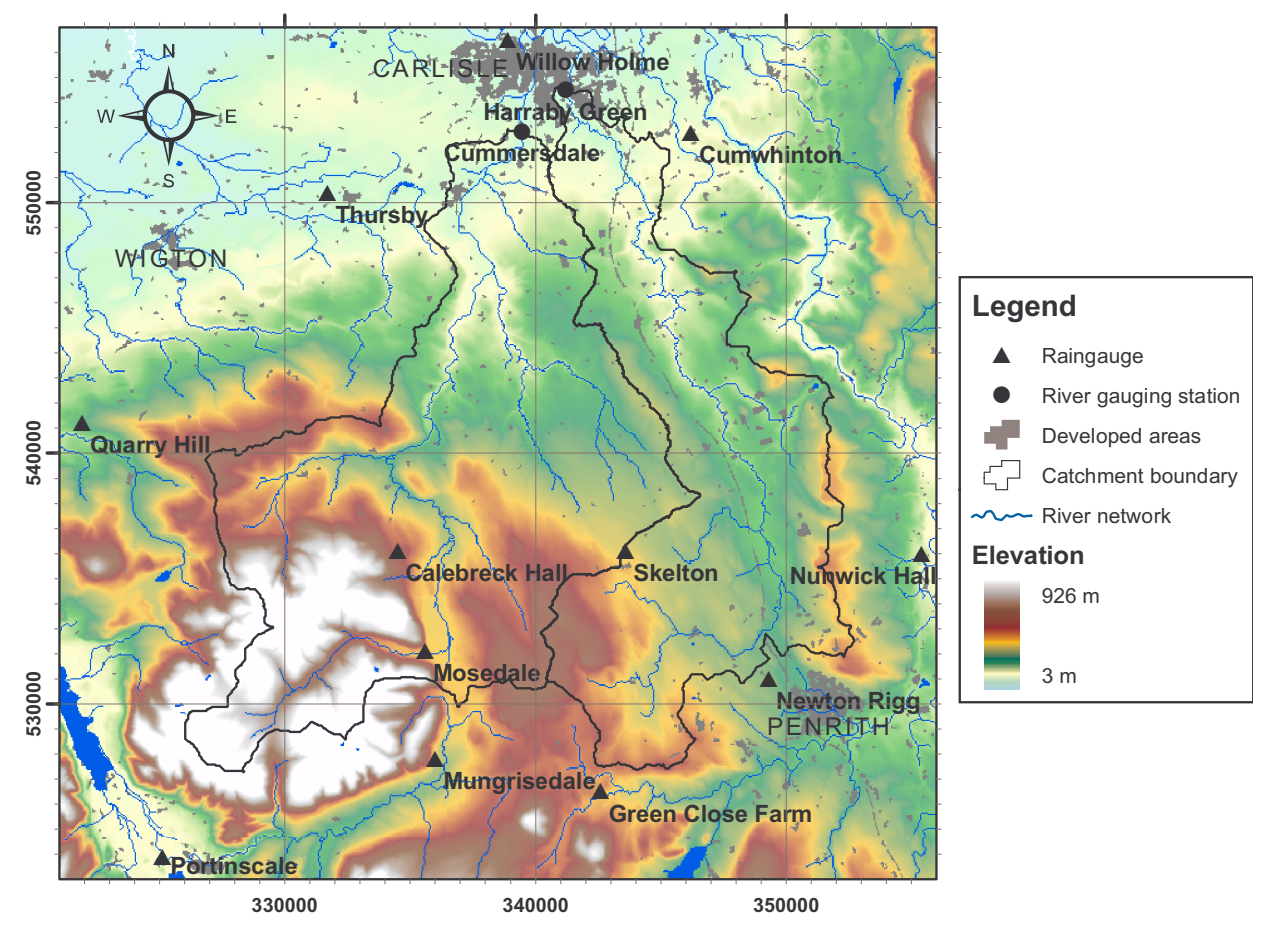

Figure 9. Location map for the adjacent River Caldew (west) and River Petteril (east) catchments and associated hydrometric network.

NWP rainfalls, from models of differing resolution, should become apparent in their forecast flood responses.

The catchment boundaries delineated in Figure 9 are for river gauging stations on the two tributaries: the Caldew at Cummersdale $\left(246 \mathrm{~km}^{2}\right)$ and the Petteril at Harraby 
Green $\left(160 \mathrm{~km}^{2}\right)$. These stations serve an important flood warning function. The area displayed in Figure 9 corresponds to the squares in Figures 7 \& 8 .

The Caldew catchment has an altitude range from 23 to $926 \mathrm{~m}$ and the steep headwaters make for a responsive hydrograph. The river gauging station at Cummersdale is situated just southwest of Carlisle, approximately $4.5 \mathrm{~km}$ upstream of the confluence of the Caldew with the Eden. The flood peak stage of $3.15 \mathrm{~m}$ recorded during the flood event at 03:15 8 January 2005 is the highest on record (from 1977) and is just above the bankfull level.

The long and narrow Petteril catchment has its headwaters in the moorland west of Penrith and flows north towards Carlisle. It is less steep over much of its length than the Caldew and has a slower catchment response (see Figure 9). Altitude ranges from 20 to $366 \mathrm{~m}$. The gauging station at Harraby Green in the south of Carlisle is about $2 \mathrm{~km}$ upstream of the confluence with the Eden. The flood peak stage of 1.86 $m$ recorded during the flood event at 07:30 8 January 2005 is the highest on record (from 1970).

Both river gauging stations are used to support flood warning for areas within Carlisle (see Environment Agency, 2005). The rating equations (used to convert river level measurements to flow) applied in this study are those that were in use at the time of the January 2005 event. These equations have since been reviewed and revised (Environment Agency, 2007).

The flooding mechanisms which caused the initial onset of flooding during the January 2005 event on the Caldew were complex and included surcharging of sewers in the Willow Holme area and flooding due to blockages at South Vale footbridge. This caused the onset of flooding earlier than would be predicted using a real-time flood forecasting model, reducing the lead-time provided by model forecasts. As is currently the case operationally, forecasts in this study only consider flooding from main river and do not consider blockages.

\subsection{PDM model description}

The Probability Distributed Model (PDM) of Moore $(1985,2007)$ is a conceptual rainfall-runoff model which converts rainfall and potential evaporation input timeseries data to flow at the outlet of a river catchment (if gauged, historical records can be used for model assessment). Runoff production resulting from rainfall is controlled by assigning a probability density function to represent the variability of the absorption capacity of the canopy, surface and soil across the catchment. Translation to the catchment outlet of this 'direct runoff' together with 'soil drainage to groundwater' is represented by fast and slow storage functions. These act in parallel to give the surface runoff and baseflow components of the total river flow. The PDM has been widely used throughout the world and has now evolved to become a practical toolkit for rainfall-runoff modelling and forecasting. The PDM's runoff production component has also been incorporated into MOSES, the Met Office Surface Exchange Scheme (Essery et al., 2001), for use in the Nimrod nowcasting system (Smith et al., 2006).

\subsubsection{Calibration of the PDM model}

Data for the years 2004 and 2005 were analysed for suitable model calibration events that excluded the flood event of interest. Three periods were chosen of varying length and season. They were: 
1. 09:00 30 January $2004-09: 0012$ February 2004

2. 09:00 1 August $2004-09: 001$ November 2004

3. 09:00 9 October 2005 - 09:00 24 November 2005

The calibration process was split into two parts. Firstly, the process model parameters were calibrated in simulation-mode where the model deterministically calculates simulated flow using only the input data (rainfall and potential evaporation), completely ignoring the observed flow (except for model initialisation). Secondly, when considering the real-time flood forecasting application the model was run in forecast-mode which aims to emulate real-time application in an off-line environment.

When the PDM model simulations for both catchments were compared to observed flows it was found that the calibrations were good at both sites with a particularly good calibration for the Caldew. This gave confidence in the results that might be obtained for the January 2005 Carlisle flood case (even though more extreme).

\subsection{The forecasts used}

Rainfall accumulations every 15 minutes were input to the PDM from the 12,4 and 1 $\mathrm{km}$ Unified Model forecasts that started at 06, 12 and 18 UTC on the $7^{\text {th }}$ January (FC3, FC4 and FC5 in Figure 6). The information provided to the PDM began three hours into the forecasts (two hours into the 4 and $1 \mathrm{~km}$ grid-length simulations) at 09 , 15 and 21 UTC and was fed in for ten hours. This is depicted in Figure 6 by the thick arrows drawn to highlight the relevant parts of forecasts FC3, FC4 and FC5.

In addition, 15-minute accumulations on a $5 \mathrm{~km}$ grid from the Nimrod nowcasting system were fed in; starting at the same times, but only running for 6 hours (as operationally). The nowcasting system is expected to be reasonably accurate for a few hours, but have limited usefulness after that. The current best practice for flood forecasting and warning within the Environment Agency employs rain gauge rainfall, Nimrod rainfall forecasts out to 6 hours and NWP forecasts beyond this.

\subsection{Results}

Figure 10 shows a comparison of catchment averages calculated from the UM, Nimrod and rain gauge data over the three 10 hour forecast periods for the Caldew and Petteril catchments respectively. A spatial distribution of the rain gauge data was obtained by using a multiquadric surface fitting technique (Moore et al., 1989; Balascio, 2001; Moore et al., 2007). The rain gauge catchment average provides a valuable observation reference against which the UM and Nimrod forecasts may be compared.

The main result to come from the comparison of the different UM forecasts is the large difference between the $12 \mathrm{~km}$ forecast and the finer resolutions. The 1 and 4 $\mathrm{km}$ forecasts were in considerably better agreement with the observed rain gauge rainfall than the $12 \mathrm{~km}$ mesoscale model. This agrees with the previous findings from the 24-hour accumulation period (section 3). The $1 \mathrm{~km}$ model generally produced more rain than the $4 \mathrm{~km}$ model, which also agrees with the results in section 3 . The most noticeable difference between the 1 and $4 \mathrm{~km}$ model results was in the Caldew catchment, which reflects the greater orographic influence that affects the Caldew (see Figure 9), and fits with where the greatest 24-hour accumulation differences were seen (Figures 7 and 8 ). 
The other clear signal that comes from Figure 10 is the similarity between the $12 \mathrm{~km}$ model and Nimrod. This is not surprising as the Nimrod prediction system used the $12 \mathrm{~km}$ model for orographic enhancement of rainfall and increasingly blended in the $12 \mathrm{~km}$ model as forecast time increased (Golding, 1998).

The PDM forecasts are presented in Figure 11 for the Caldew and Petteril catchments respectively. The four types of rainfall forecast previously discussed (12, 4 and $1 \mathrm{~km}$ UM and Nimrod rainfall forecasts) were used to produce river flow forecasts out to 16 hours. These are compared to a reference forecast containing rain gauge data which acts as a 'perfect knowledge' of the future catchment rainfall up to 10 hours ahead. To obtain the 16 hour lead-time flow forecasts, 6 hours of zero rainfall appends the NWP and rain gauge forecasts whilst 10 hours append the Nimrod rainfall forecast.
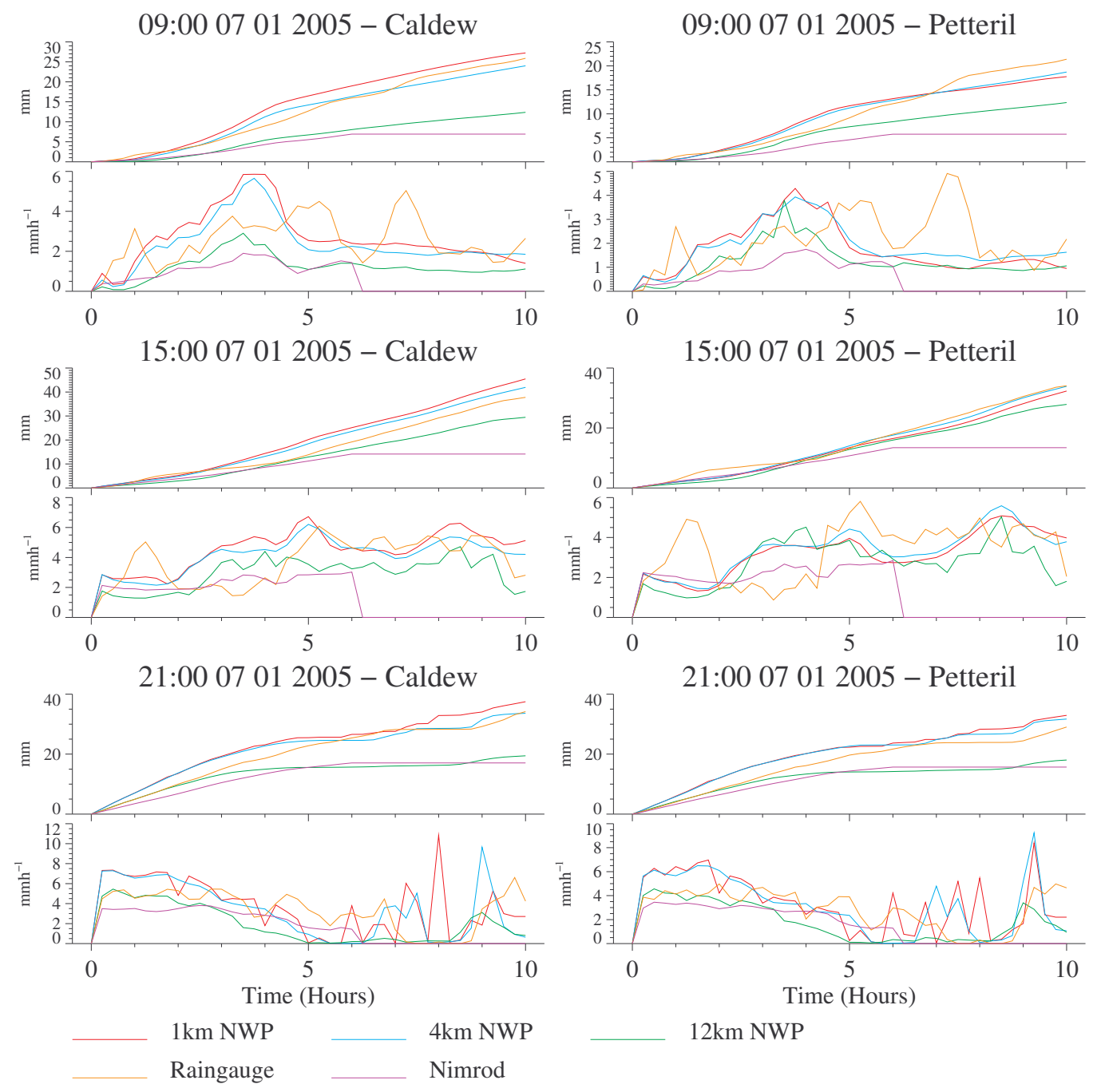

$12 \mathrm{~km} \mathrm{NWP}$

Figure 10. NWP model, Nimrod and rain gauge hyetographs for the Caldew and Petteril catchments, over $\mathbf{1 0}$ hour periods starting at the date shown. Note that the Nimrod forecast is only 6 hours long.

The first thing to notice is that the flow from the rain gauge reference forecast is generally in agreement with the observed flow. A comparison of the PDM forecasts 
from the different UM resolutions shows that the $1 \mathrm{~km}$ forecasts almost always produced the highest river flows, followed by the $4 \mathrm{~km}$ forecasts, with the $12 \mathrm{~km}$ forecasts significantly lower. Focussing first on the Caldew catchment, this meant that the 15 and 21 UTC PDM forecasts using the $1 \mathrm{~km}$ and $4 \mathrm{~km}$ UM gave an overprediction of river flow; the $1 \mathrm{~km}$ more so than the $4 \mathrm{~km}$. However, the PDM forecast from 09 UTC using the $1 \mathrm{~km}$ model was extremely close to the observed flow. The PDM flows obtained using the $12 \mathrm{~km}$ UM and Nimrod rainfalls were generally similar over the Nimrod forecast period and they were both too low by a significant amount. The results from the Petteril catchment were broadly similar, with the 4 and $1 \mathrm{~km}$ forecasts giving considerably better results than the $12 \mathrm{~km} \mathrm{UM}$ and Nimrod forecasts over all three periods.
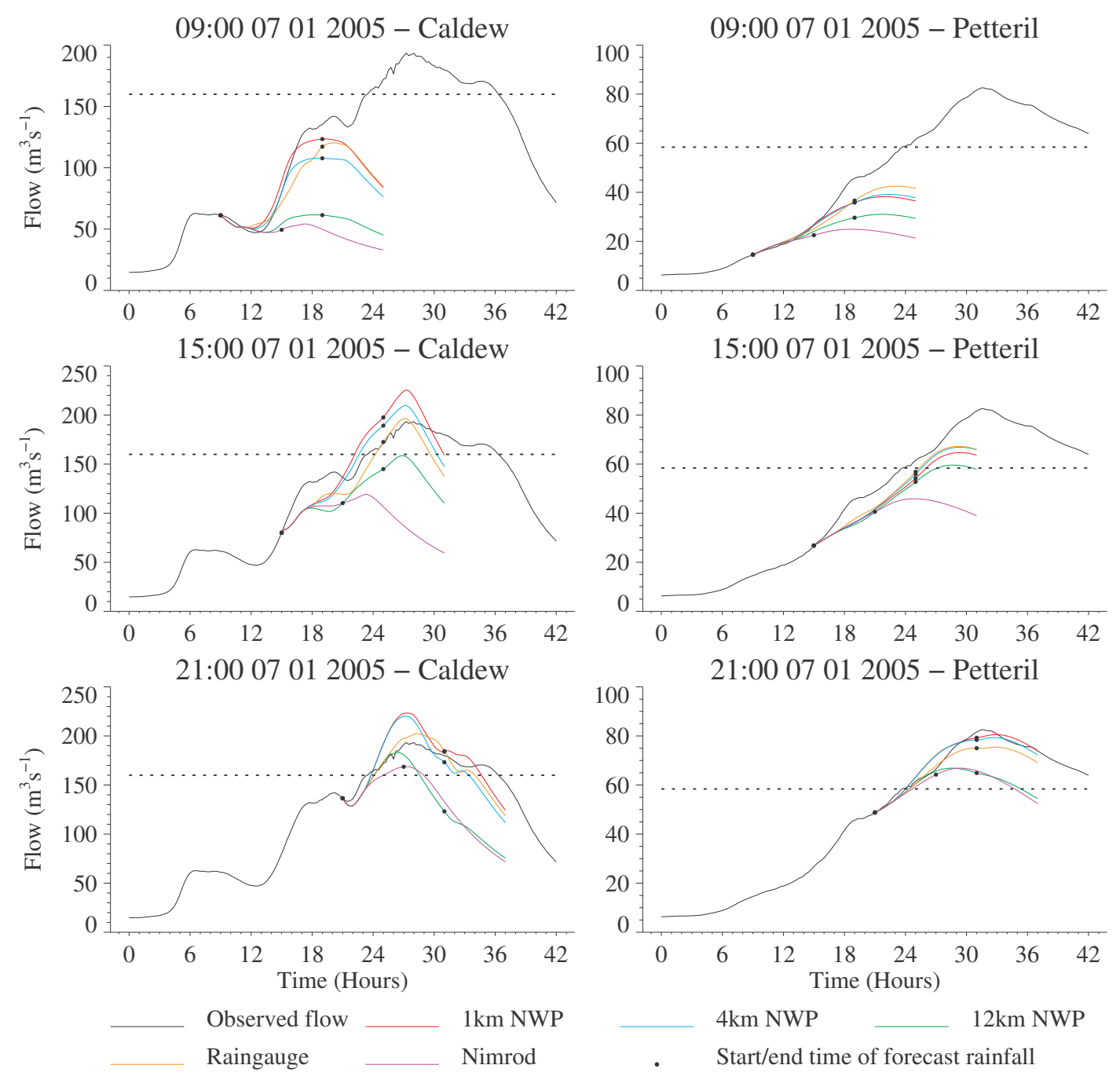

Figure 11. PDM river flow forecasts out to 16 hours for the Caldew and Petteril catchments using NWP model, Nimrod and rain-gauge rainfall forecasts. The solid dots indicate the start and end time of the rainfall forecast data. Note that the Nimrod forecast is only 6 hours long compared to 10 hours for the other forecast types. The horizontal dashed line is the 'flood warning' level.

Having seen that the high resolution NWP forecasts were substantially different to the $12 \mathrm{~km}$ model, it is worthwhile to consider what this might have meant in an operational context if they had been available at the time. A closer inspection of the 
PDM forecasts from 15 UTC shows the potential benefit high resolution NWP rainfalls can have for flood warning. The 6 hour lead time of the Nimrod forecast is not sufficient to predict the flood peak or even cross the 'flood warning' threshold. The longer lead-time of the mesoscale $12 \mathrm{~km}$ model does improve the PDM forecast and just approaches the 'flood warning' threshold for both catchments. However, the greater accumulations predicted by the higher resolution 1 and $4 \mathrm{~km}$ models mean that the PDM simulations cross the 'flood warning' threshold by some margin and could have allowed a flood warning to be issued for parts of Carlisle around 12 hours earlier than happened in practice. Clearly, flood forecasts based on high resolution NWP rainfall in combination with rainfall-runoff models would need to be shown to be reliable over a range of events before being accepted to support operational decisions at long lead-times (before observed river levels have confirmed their forecast is sound). Through continuing improvements in such prediction tools, and their extension to include estimates of forecast uncertainty, they can be expected to play an increasing role in the complex decision-making underlying flood warning and emergency response coordination.

Whilst it could be argued that the over-prediction of the $1 \mathrm{~km}$ model helped in this instance, it should be remembered that the frontal rain was too high at all three resolutions. If the frontal precipitation had been less, the totals would have decreased in all the forecasts, but this is unlikely to have significantly delayed the time at which the flood warning threshold was exceeded from the 1 and $4 \mathrm{~km}$ rainfall forecasts. It would however have meant that the flow from the $12 \mathrm{~km}$ forecast would have missed the warning threshold for the Petteril as well as the Caldew catchments. Therefore use of high-resolution forecasts could still have allowed an improvement in flood-warning lead time of around 12 hours or more for the January 2005 event.

\section{Conclusions}

The flooding in Carlisle on the $8^{\text {th }}$ January 2005 came about as the result of a prolonged period of orographically enhanced rain over Cumbria in northwest England. Although this was an unusual event in terms of the quantity of rain that fell, the orographic enhancement of rain from the seeder-feeder mechanism is not unusual for that area, and can be represented in NWP models provided that the hills are sufficiently well resolved.

It has been shown that forecasts from the Met Office Unified Model with a grid spacing of 1 or $4 \mathrm{~km}$ were capable of producing more accurate predictions of the rainfall than the $12 \mathrm{~km}$ model operational at the time. The rainfall forecasts from the 12,4 and $1 \mathrm{~km}$ models along with nowcasts from the Nimrod system were then used as input to the PDM rainfall-runoff model to predict river flows at two gauging stations important for flood warning. The results show the clear benefit of coupling highresolution NWP model output with a hydrological model and confirmed the improvement in the prediction of the event from the 4 and $1 \mathrm{~km}$ forecasts. Had the 1 or $4 \mathrm{~km}$ models been available for input to the PDM at the time, a flood warning could have been issued to parts of Carlisle around 12 hours earlier than happened in practice. Confidence in both the NWP rainfalls and the flood forecasting model would need to be developed, however, before such an approach could form a routine part of the flood warning process. The Carlisle flood provides an indication of the potential benefits of such warnings: for the areas affected by the lower Petteril and Caldew as many as 363 properties were at risk.

Although this was only one case (with deficiencies), we still believe it demonstrates the value of kilometre-scale NWP rainfall forecasts for flood warning. When used as 
input to appropriate hydrological models, such rainfall forecasts can provide earlier flood warnings (up to $\sim 12$ hours ahead for this type of situation) than was possible back in January 2005 when only the $12 \mathrm{~km}$ model rainfalls were available. Our confidence comes from a belief that, over a short forecast period, current NWP forecast models are sufficiently reliable on the mesoscale (location of fronts, etc.). The orographic enhancement will be well represented because the orography is adequately resolved. Beyond $\sim 12$ hours ahead, the mesoscale uncertainty becomes increasingly important, and a more probabilistic approach becomes increasingly desirable, but still using high-resolution NWP forecasts. Convective situations will present more difficulty because they are typically less predictable on these scales and a probabilistic approach will be required from shorter forecast lead times.

The Met Office now operationally runs a $4 \mathrm{~km} \mathrm{NWP} \mathrm{model} \mathrm{and} \mathrm{it} \mathrm{is} \mathrm{planned} \mathrm{to}$ improve this to $1.5 \mathrm{~km}$ for the turn of the decade. So the time is now right to make greater use of NWP rainfall forecasts with hydrological models in flood warning systems, with the prospect of earlier warnings and better preparedness leading to reduced flood damage costs. 


\section{Acknowledgements}

The rain gauge and river flow data used in the study were provided by the Environment Agency. In particular, thanks are due to Helen Stanley and Susan Taylor for support and supply of information. At CEH, this work was undertaken as part of the Natural Environment Research Council FREE (Flood Risk from Extreme Events) programme. At the Met Office, this work was partly funded by the Joint Defra/EA Flood and Coastal Erosion Risk Management R\&D programme.

\section{References}

Bader MJ, Roach WT. 1977. Orographic rainfall in small sectors of depressions. Quarterly Journal of the Royal Meteorological Society 103: 269-280.

Balascio CC. 2001. Multiquadric equations and optimal areal rainfall estimation. Journal of. Hydrologic Engineering 6(6): 498-505.

Browning KA. 1980. Structure, mechanism and prediction of orographically enhanced rain in Britain. In: Hide R, West PW (Eds.), Orographic effects in planetary flows. GARP Publication Series No. 23, WMO, Geneva, 85-114.

Davies T, Cullen, MJP, Malcolm AJ, Mawson MH, Staniforth A, White AA, Wood N. 2005. A new dynamical core for the Met Office's global and regional modelling of the atmosphere. Quarterly Journal of the Royal Meteorological Society 608: 1759-1782.

Environment Agency. 2005. Dealing with flooding - A review of the floods in northern England and North Wales January 2005. Environment Agency, 17pp.

Environment Agency. 2006. Cumbria Floods Technical Report. Factual report on meteorology, hydrology and impacts of January 2005 flooding in Cumbria. Report of team consisting of Black \& Veatch, Met Office and Environment Agency, November 2006, 168pp. (Available from http://publications.environment-agency.gov.uk, Product Code GENW1106BLSF-E-E.)

Environment Agency. 2007. Eden Flood Forecasting Model Update: Phase I. Environment Agency, 28pp plus Appendices.

Essery R, Best M, Cox P. 2001. MOSES 2.2 Technical Documentation, Hadley Centre Technical Report No. 30, Met Office Hadley Centre.

Golding BW. 1998. Nimrod: A system for generating automated very short range forecasts. Meteorological Applications 5(1): 1-16.

Gregory D, Rowntree PR. 1990. A mass flux convection scheme with representation of cloud ensemble characteristics and stability-dependent closure. Monthly Weather Review 118: 1483-1506.

Hill FF, Browning KA, Bader MJ. 1981. Radar and rain-gauge observations of orographic rain over south Wales. Quarterly Journal of the Royal Meteorological Society 107: 643-670. 
Jones CD, Macpherson B.1997. A latent heat nudging scheme for the assimilation of precipitation data into an operational mesoscale model. Meteorological Applications 4: $269-277$.

Lean HW. 2002. Simulation of orographic rainfall in South Wales with UM Version 5.2. Met Office Scientific Report 70, available on request.

Lock AP, Brown AR, Bush MR, Martin GM, Smith RNB. 2000. A new boundary layer mixing scheme. Part 1: scheme description and single-column model tests. Monthly Weather Review 128: 3187-3199.

Lorenc, AC, Ballard SP, Bell RS, Ingleby NB, Andrews PLF, Barker, DM, Bray JR, Clayton AM, Dalby TD, Li D, Payne, TJ, Saunders FW. 2000. The Met. Office global three-dimensional variational data assimilation scheme. Quarterly Journal of the Royal Meteorological Society 126: 2991-3012.

Moore RJ. 1985. The probability-distributed principle and runoff production at point and basin scales. Hydrological. Sciences Journal 30(2): 273-297.

Moore RJ. 1999. Real-time flood forecasting systems: perspectives and prospects. In: Casale R, Margottini C. (Eds.), Floods and Landslides: Integrated Risk Assessment, Springer, Berlin, Germany, Chap. 11: 147-189.

Moore RJ. 2007. The PDM rainfall-runoff model. Hydrology and Earth System Sciences, 11(1): 483-499.

Moore RJ, Bell VA, Cole SJ, Jones DA. 2007. Spatio-temporal rainfall datasets and their use in evaluating the extreme event performance of hydrological models. R\&D project FD2208, Report to the Environment Agency and Defra, CEH Wallingford, 259pp.

Moore RJ, Watson BC, Jones DA, Black KB. 1989. London weather radar local calibration study: final report. Contract report prepared for the National Rivers Authority Thames Region, September 1989, Institute of Hydrology, 85pp.

Raymond WH. 1988. High-order low-pass implicit tangent filters for use in finite area calculations. Monthly Weather Review 116: 2132-2141.

Roberts NM, Lean HW. 2008. Scale-selective verification of rainfall accumulations from high-resolution forecasts of convective events. Monthly Weather Review 136: 78-97.

Smith RNB, Blyth EM, Finch JW, Goodchild S, Hall RL, Madry S. 2006. Soil state and surface state hydrology diagnosis based on MOSES in the Met Office Nimrod nowcasting system. Meteorological Applications 13: 89-109.

Westrick J, Mass CF. 2001. An evaluation of a high-resolution hydrometeorological modelling system for prediction of a cool-season flood event in a coastal mountainous watershed. Journal of Hydrometeorology 2: 161-180

Wilson DR, Ballard SP. 1999. A microphysically based precipitation scheme for the UK Meteorological Office Unified Model. Quarterly Journal of the Royal Meteorological Society 125: 1607-1636. 